\title{
The Important Value and Function of Inheriting the Spirit of Beidahuang to the Cultivation of Talents under the Background of Revitalization in the Northeast of China
}

\author{
Yingce Zhan, Mingcong Zhang , Yaowu Jin \\ Heilongjiang Bayi Agricultural University, Daqing 163319, China
}

DOI: $10.36348 /$ sijll.2020.v03i03.001 | Received: 02.03.2020 | Accepted: 10.03.2020 | Published: 13.03 .2020

*Corresponding author: Mingcong Zhang

\section{Abstract}

Since the 18th National Congress of the Party, the Central Committee has issued a series of major decision-making arrangements for comprehensively revitalizing the Northeast region and other old industrial bases, thus promoting the northeast rejuvenation to develop in-depth. High-quality development in the Northeast cannot be separated from talent. The spirit of Beidahuang is the precious spiritual wealth formed in the historical process of large-scale development and construction in Northeast China. Under the background of northeast revitalization, Inheriting and carrying forward the spirit of Beidahuang has important value and function to strengthen the work of talent training.

Keywords: The Spirit of Beidahuang; Revitalization in the northeast of China; Talent Training.

Copyright @ 2020: This is an open-access article distributed under the terms of the Creative Commons Attribution license which permits unrestricted use, distribution, and reproduction in any medium for non-commercial use (NonCommercial, or CC-BY-NC) provided the original author and source are credited.

\section{INTRODUCTION}

General Secretary of the CPC Central Committee, State President and Chairman of the Central Military Commission, Xi Jinping, visited the three Northeast provinces in September 2018, presided over the in-depth development of the Northeast revitalization forum and delivered an important speech, first came to Heilongjiang Agricultural Reclamation and Construction of the Sanjiang River Administration to understand the situation of grain production and harvest. He stressed that the old industrial bases should seize the opportunity and work hard to implement the new concept of development, deepen the reform and opening up, optimize the development environment, stimulate innovation and vitality, and open up a new way to revitalize development under the new situation [1].

Revitalization and development cannot be separated from the support of the spirit, the formation and development of the spirit of Beidahuang have a profound social and historical background, the content is fresh and easy to be perceived. While constantly combing and condensing the history of the Spirit of Beidahuang, the spirit of Beidahuang in the process of entrepreneurship embodies the unique spirit style, value orientation and noble sentiment, valuable collectivism spirit and patriotism spirit, is also deeply excavated and applied by scholars. The spirit of Beidahuang, which has the profound connotation of the national spirit and the vitality of the new era spirit, is the common spiritual wealth of the whole society. It is of great value and farreaching significance to carry forward the spirit of Beidahuang [2].

\section{It helps to cultivate students' spirit of exploration}

In 1947, Mao Tse-tung made a great call for "the establishment of a consolidated northeast base area", which opened the prelude to the development and construction of the great famine. After half a century, honed the "painstaking efforts of pioneering spirit, the innovative spirit of daring to open, the unity spirit of pay attention to the interest of the whole, the service spirit of selfless dedication" as the main content of the precious spiritual wealth - the spirit of Beidahuang. The spirit of Beidahuang inspired generations of people to fight for the country, dedication.

Northeast revitalization cannot be separated from outstanding talents; talent training cannot be separated from the support of culture and spirit. We should make full use of the unique spiritual wealth of the Beidahuang, guide the young people to draw spiritual strength from it, grasp the essence of the essence, and strive for a thorough understanding of the basic contents and basic requirements of the Spirit of Beidahuang. To integrate the spiritual resources of the 
Beidahuang into talent training, it is beneficial to cultivate students' ability of innovation and entrepreneurship, and to strengthen students' sense of mission in society. Inheriting and carrying forward the spirit of Beidahuang can also enable students to actively participate in the economic construction of reclamation areas and help the rapid development of the regional economy.

\section{It helps to enrich students' knowledge system}

The spirit of "painstaking efforts of pioneering spirit, the innovative spirit of daring to open, the unity spirit of pay attention to the interest of the whole, the service spirit of selfless dedication" has encouraged generations of people to devote themselves to the great practice of cultivating and defending the border and ensuring food security for the country. In the course of the development and construction of the Beidahuang, numerous touching cases have emerged, affecting the people of the reclamation area from generation to generation.

In the new era, the realization of agricultural modernization is the basic requirement of building a socialist modern power. College students are the main force and fresh force in socialist modernization construction; they are the key groups to realize agricultural modernization. Students understand the formation process of the Spirit of Beidahuang through various ways, and understand the connotation and the value of the times of the Spirit of Beidahuang. Such as reading related books, watching online video courses, visiting pavilions, expert discussions, visiting enterprises, farm training and so on. The process of learning the spirit of Beidahuang is the process of enriching the knowledge system and increasing the ability. Through understanding modern agriculture, understanding mechanized operations, deepening students' understanding of agricultural reclamation, understanding of Chinese agriculture, so that students can consciously devote themselves to the modernization of reclamation areas and become more conscious practitioners of the spirit of Beidahuang[3].

\section{It helps to improve students' innovation ability}

During the development period, the pioneers climbed ice and snow, drained the marshes, reclaimed the wasteland, and established many state-owned and military farms. It has produced a lot of grain for the country and turned the barren land of the past into a beautiful and rich granary.

Integrating the spirit of Beidahuang resources into talent training, to realize the organic unity of theory and practice with the aid of the vivid and intuitive educational resources of Beidahuang, turn abstraction into concrete, through situational teaching and new media teaching and other means, can enhance the effectiveness of talent training. The integration of the spirit of the Beidahuang resources into talent training is of great significance to the cultivation of students' ability of resource utilization, knowledge application, analysis, innovation and contingency.

\section{CONCLUSION}

The Communist Party of China and the state have always attached great importance to the building of spiritual civilization, through the construction of spiritual civilization to improve the ideological and moral level and cultural literacy of the whole nation, to provide ideological guarantee and intellectual support for the overall construction of a modern socialist country.

The Party Central Committee and the state attach importance to the development of the Heilongjiang Reclamation Area and propose that we should vigorously carry forward the spirit of Beidahuang and pass on the spirit of Beidahuang from generation to generation. The spirit of Beidahuang is the spiritual asset that the Chinese nation needs to inherit forever. Only with a high degree of recognition of the spirit of Beidahuang can college students devote themselves to the modernization of agriculture, and in the process of construction to pass on the spirit of Beidahuang, so that the new era of college students become the practitioners of the spirit of Beidahuang, inheritors, and builders.

\section{ACKNOWLEDGEMENTS}

This work was supported by General Research Projects on Higher Education and Teaching Reform in Heilongjiang Province (SJGY20190482), Teaching Research Project of Review and evaluation of Heilongjiang Bayi Agricultural University (NDJY1801), The Doctoral Scientific Research Start-up Foundation of Heilongjiang Bayi Agricultural University of China (No. XYB2014-04), Youth Special Project in the 13th Five-Year Plan of Education Science in Heilongjiang Province (GJD1318025).

\section{REFERENCES}

1. An B, Xu Y, Wang W. Realizing the Comprehensive Revitalization of the Northeast in the New Era Interpretation of General Secretary Xi Jinping's Important Speech at the Symposium on Further Promoting the Revitalization of the Northeast [N]. Xinhua Net. 2018; 09, 29.

2. Wang CH. Study on the spirit of Beidahuang and Contemporary Value [J]. Journal of Heilongjiang Institute of Socialism. 2010; (3):51-53.

3. Yang LY, Chen WB. Popularizing the Great Northern Wilderness Spirit and Strengthening Work of College Students' Ideological and Political Education [J]. Journal of Northeast Agricultural University (Social Science Edition). 2012; 10(03):30-32. 